\title{
Characterization of fly ash ceramic pellet for phosphorus removal
}

\author{
Shiyang Li
}

Department of Agricultural and Biological Engineering, University of Illinois at Urbana

Champaign

Correspondence author: Rabin Bhattarai, Department of Agricultural and Biological

Engineering, University of Illinois at Urbana Champaign, Address: 1304 W Pennsylvania Ave \#332L, Urbana IL, USA;

E-mail: rbhatta2@illinois.edu; Phone: +1-217-300-0001 


\title{
Characterization of fly ash ceramic pellet for phosphorus removal
}

\author{
Shiyang Li ${ }^{\mathrm{a}, \mathrm{b}}$, Richard A. Cooke ${ }^{\mathrm{a}}$, Li Wang ${ }^{\mathrm{b}}$, Fang Ma ${ }^{\mathrm{b}}$, Rabin Bhattarai $^{\mathrm{a}}$ \\ ${ }^{a}$ Department of Agricultural and biological Engineering, University of Illinois at Urbana \\ Champaign, 1304 W Pennsylvania Ave, Urbana IL 61801, USA \\ ${ }^{\mathrm{b}}$ State Key Lab Urban Water Resource \& Environment, Harbin Institute of Technology, \\ No.73 HuangHe Road, Harbin 150090, Peoples R China
}

\begin{abstract}
Phosphorus has been recognized as a leading pollutant for surface water quality deterioration. In the Midwestern USA, subsurface drainage provides a pathway for excess water to leave the field but it also drains out nutrients like nitrogen $(\mathrm{N})$ and phosphorus (P). Fly ash has been identified as one of the viable materials for phosphorus removal from contaminated waters. In this study, a ceramic pellet was manufactured using fly ash for $\mathrm{P}$ absorption. Three types of pellet with varying lime and clay proportions by weight (type $1: 10 \%$ lime $+30 \%$ clay, type $2: 20 \%$ lime $+20 \%$ clay, and type $3: 30 \%$ lime $+10 \%$ clay) were characterized and evaluated for absorption efficiency. The result showed that type 3 pellet (60\% fly ash with $30 \%$ lime and $10 \%$ clay) had the highest porosity (14\%) and absorption efficiency and saturated absorption capacity (1.98 $\mathrm{mg} \mathrm{P} / \mathrm{g}$ pellet)
\end{abstract}


compared to type 1 and 2 pellets. The heavy metal leaching was the least $(30 \mu \mathrm{g} / \mathrm{L}$ of Chromium after 5 hours) for type 3 pellet compared to other two. The microcosmic structure of pellet from scanning electron microscope showed the type 3 pellet had the better distribution of aluminum and iron oxide on the surface compared other two pellets. This result indicates that addition of lime and clay can improve $\mathrm{P}$ absorption capacity of fly ash while reducing the potential to reduce chromium leaching.

Keywords: Pollutant; subsurface drainage; Non-point source pollution; water quality. 


\section{Introduction}

Phosphorus (P) has been considered as the critical element to cause eutrophication (Daigh et al., 2015; Smith et al., 2015; Su et al., 2014) because P is the limiting nutrient for algal bloom (Kleinman et al., 2015). Phosphorus loss from agricultural areas has been a major water quality concern throughout the world (Kronvang et al., 2007; Li et al., 2010; Liu et al., 2006). Past studies have shown that $P$ loss occurs predominantly in surface runoff (Melland et al., 2008; Smith et al., 2015; Uusitalo et al., 2001; Wright et al., 2001). However, recent studies have demonstrated that subsurface drainage is another major source of P loss from the tiled-drained watersheds in Midwestern USA (Baker et al., 1975; Bhattarai et al., 2009; Heathwaite and Dils, 2000; King et al., 2015; Laubel et al., 1999; Smith et al., 1995). Ruark et al. (2012) reported that nearly 16 - $58 \%$ of dissolved P loads were contributed by tile drainage in Wisconsin. King et al. (2015) summarized previous studies and found that $\mathrm{P}$ concentrations varied spatially and temporally in tile drains (< 0.01 to $>8.0 \mathrm{mg} / \mathrm{L})$ but generally exceeded a critical limit of eutrophication $(0.02-0.03$ $\mathrm{mg} / \mathrm{L}$ ). Based on the analysis of 16 years of water quality data from three tile-drained watersheds in east-central Illinois, Gentry et al. (2007) reported that the average annual flow-weighted total phosphorus (TP) concentration exceeded $0.2 \mathrm{mg} / \mathrm{L}$. Eastman et al. (2010) investigated P transport under tile drainage and naturally drained condition for two years and found that tile drainage had 1.5 times higher P load than the naturally drained farmland. In Minnesota, dissolved P concentrations ranged from 0.1 to $0.9 \mathrm{mg} / \mathrm{L}$ 
at the tile outlets from two large depressions with catchment areas of 44.3 and 41.5 ha (Ginting et al., 2000).

Preferential flow has been considered as the probable cause for $\mathrm{P}$ transport through subsurface tile (Gachter et al., 1998; King et al., 2015; Kung et al., 2000; Stone and Wilson, 2006). Simard et al. (2000) reported that preferential flow pathways might be particularly important after storm events that rapidly follow periods of drought and surface P inputs as inorganic fertilizer or manure. Nielsen et al. (2010) irrigated two areas field with dye water for 8 hours, and the vertical section showed many dyed biopores up to $150 \mathrm{~cm}$ depth and staining continued farther down in fractures. Redox conditions of soil can also be a possible reason for P loss to subsurface drainage (Braskerud et al., 2005). The high positive redox potential probably conserves the redox-sensitive phosphorus in the wet condition. Type of soil and drainage design can also impact $\mathrm{P}$ transport in subsurface flow (Allen et al., 2012; Eastman et al., 2010; Hornbuckle et al., 2007; Reid et al., 2012; Van Es et al., 2004). These studies confirmed that finer-textured soils had much better absorption ability of $\mathrm{P}$ but also facilitated preferential flow pathway, and the shallower subsurface drainage pipe resulted in higher P loss.

In-stream and end-of-tile treatment have been recommended as effective practices to control P loss from the agricultural area (Allred, 2010; Bird and Drizo, 2010; Bock et al., 2016; Penn et al., 2007; Vohla et al., 2011; Westholm, 2006). Earlier studies have used metal turnings (Goodwin et al., 2015), biochar (Soinne et al., 2014), zeolite, fly ash and 
modified zeolite (Allred, 2010) to filter out phosphorus from water. Fly ash has been considered as an efficient and cheap byproduct for $\mathrm{P}$ absorption because it is readily available and rich in $\mathrm{Ca}, \mathrm{Al}, \mathrm{Fe}$ oxides (Allred, 2010). But fly ash also contains toxic heavy metals such as mercury, chromium, lead, arsenic, copper, and cadmium, which can have adverse health and environmental impacts.

Several materials have been tested to immobilize the heavy metals during the application of fly ash in water treatment practice. Xu et al. (2006) reported that Metakaolin mixed with alkali activator solution could restrict $\mathrm{Cu}$ and $\mathrm{Cd}$ leaching concentration under $88 \mu \mathrm{g} / \mathrm{L}$ and $40 \mu \mathrm{g} / \mathrm{L}$, respectively. Karlfeldt Fedje et al. (2010) used alternative media (EDTA, Ammonium nitrate, ammonium chloride and organic acid) to treat fly ash and reduce the heavy metal leaching. Jankowski et al. (2006) found that pH was the key factor affecting the mobility of heavy metal. Izquierdo and Querol (2012) reported that the leaching of most trace elements in fly ash reduced in $\mathrm{pH}$ 7-10 region, indicating alkalinity additives would help in immobilizing heavy metal in fly ash. The objective of this study was to develop ceramic pellets using fly ash and other additives with minimum or no heavy metal leaching. Inexpensive and easily available materials such as lime and bentonite clay were used as additives in various proportions to prevent heavy metal leaching from fly ash pellets.

\section{Materials and methods}

\subsection{Fly ash ceramic pellet preparation}


Fly ash (FA) was obtained from Abbott Power Plant, Urbana, IL, USA. The basic chemical composition of fly ash is $35.8 \% \mathrm{SiO}_{2}, 28.19 \% \mathrm{Al}_{2} \mathrm{O}_{3}, 8.6 \% \mathrm{Fe}_{2} \mathrm{O}_{3}, 5.3 \% \mathrm{CaO}$, $1.9 \% \mathrm{MgO}, 2.6 \% \mathrm{Na}_{2} \mathrm{O}$, and the carbon content, measured as loss on ignition, was $17.6 \%$. The density of fly ash was measured to be $1324.7 \mathrm{~kg} / \mathrm{m}^{3}$. Fine bentonite clay was obtained from Nature's Oil, Ohio, USA. The density of clay powder was measured to be $801.1 \mathrm{~kg} / \mathrm{m}^{3}$. The lime powder was obtained from Waukesha Lime and Stone, Wisconsin, USA. The density of lime powder was measured to be $1190.24 \mathrm{~kg} / \mathrm{m}^{3}$.

At first, four different slurries of fly ash mixture with the additives were prepared. The pellet mixture contained $60 \%$ of fly ash with varying amount of lime and clay (type 1: lime $10 \%$ \& clay $30 \%$, type 2 : lime $20 \%$ \& clay $20 \%$, and type $3:$ lime $30 \%$ \& clay $10 \%$, by weight, respectively). The pellet with $60 \%$ fly ash and $40 \%$ clay was used as a reference in this study and labeled as type 0 .

All the dry materials (fly ash, lime, and clay) were mixed uniformly with a blender. Deionized water ( $15 \%$ by weight) was added to the mixture and blended again to prepare the slurry. The slurry mix was then sealed, left to stabilize for 24 hours at room temperature, then converted into pellets using a commercial pelletizer (Colorado Mill Equipment-ECO-10, USA) equipped with a $10 \mathrm{HP}$, and 208-230/460 volt, 3-phase motor. The pellets were then baked in a high-temperature furnace (Thermolyne BOX furnace, MA, USA) for a total of 7 hours, raising the temperature $200{ }^{\circ} \mathrm{C}$ each hour for 5 hours, 
then keeping it at $1000{ }^{\circ} \mathrm{C}$ for another 2 hours. Once the pellets were taken out of the oven, they were cooled down for 6 hours and then washed with distilled water.

\subsection{Pellet characterization}

For the pellet samples, bulk density was measured using Oertling YP4 balance. The porosity of the pellets was calculated using the following relationship (Equation 1):

$$
\emptyset=1-\frac{\rho_{\text {pellet }}}{\rho_{\text {material }}}
$$

where $\emptyset=$ porosity of the pellet, $\rho_{\text {pellet }}=$ density of the pellet, $\rho_{\text {material }}=$ density of fly ash, clay, and lime mixture

Elemental composition of the pellet samples was detected and measured using Environmental Scanning Electron Microscopy (ESEM) and Energy Dispersive X-ray Spectroscopy (EDS). The element distribution on surface was mapped by ESEM-EDS by interpreting the variation in absorption efficiency of each pellet.

\subsection{P absorption performance and heavy metal leaching tests}

The absorption efficiency of four types of the pellet was tested using three replicates. In each test, 50 gm pellet was added to $100 \mathrm{ml}$ of $1.0 \mathrm{mg} / \mathrm{L}$ phosphate solution and shaken at $80 \mathrm{rpm}$ at the room temperature. The samples were collected after $30 \mathrm{sec}, 1 \mathrm{~min}, 2 \mathrm{~min}, 5$ 
min, $10 \mathrm{~min}, 30 \mathrm{~min}$ and $1 \mathrm{hr}$ after placing the pellets in the solution. Then the samples were tested for phosphorus concentration. After completing the $1 \mathrm{hr}$ sorption test, all the pellets were filtrated and then put into flasks with $100 \mathrm{ml}$ DI water for desorption test. Flasks were put back to the shaker for $24 \mathrm{hr}$ with an 80rpm speed at room temperature. Solution samples were collected at 1,2,5 and $24 \mathrm{hr}$ contact time and analyzed for heavy metals using Inductively Coupled Plasma mass spectrometry (ICP-MS) test. Solution samples were collected after $24 \mathrm{hr}$ of desorption and phosphate concentration was measured.

Laboratory tests were conducted to develop the absorption isotherm for the pellets. 1 gm of the pellet was placed in $100 \mathrm{ml}$ phosphate solutions with different concentration $(0.5,1,2,5,10,50$ and $100 \mathrm{mg} / \mathrm{L})$ and left on a shaker for $24 \mathrm{hr}$. Then the pellets were removed from the solution, and phosphate concentration was measured to develop the Langmuir-Freundlich isotherm curve for each pellet type. A general form of Langmuir-Freundlich isotherm equation for $\mathrm{P}$ adsorption showed in equation (2) (Turiel et al., 2003):

$$
\mathrm{q}=\frac{Q_{s a t} * K * C_{e q}{ }^{n}}{K * C_{e q}{ }^{n}+1}
$$

where $\mathrm{q}=$ amount of $\mathrm{P}$ adsorbed on the pellet at equilibrium $(\mathrm{mg} / \mathrm{g}), \mathrm{Q}_{\text {sat }}=$ adsorption capacity of the system ( $\mathrm{mg}$ of sorbate/ $\mathrm{g}$ sorbant), Ceq = solution concentration at 
equilibrium $(\mathrm{mg} / \mathrm{L}), \mathrm{K}=$ affinity constant for adsorption $(\mathrm{L} / \mathrm{mg}), \mathrm{n}=$ index of heterogeneity.

In order analyze the effect of $\mathrm{pH}, 40 \mathrm{mg} / \mathrm{L}$ phosphate solution was mixed with appropriate amount of hydrochloric acid (HCL) to bring $\mathrm{pH}$ down to 4, 5, and 6 . Similarly, the phosphate solution was mixed with potassium hydroxide $(\mathrm{KOH})$ to elevate the $\mathrm{pH}$ to 8,9 and 10 , respectively. Then, $1 \mathrm{gm}$ of the pellet was added to the $100 \mathrm{ml}$ phosphate solution with $\mathrm{pH} 4,5,6,7,8,9$ and 10, respectively. Sample solutions were collected after $24 \mathrm{hr}$, and phosphate concentration was measured in the solution. In order to study the impact of pellet on solution $\mathrm{pH}, 1 \mathrm{gm}$ of the pellet was added into $40 \mathrm{mg} / \mathrm{L}$ phosphate solution, and solution $\mathrm{pH}$ was measured after $5 \mathrm{~min}, 10 \mathrm{~min}, 30 \mathrm{~min}, 1 \mathrm{hr}, 2 \mathrm{hr}$, $5 \mathrm{hr}$, and $24 \mathrm{hr}$.

\section{Results}

\subsection{Pellet physical properties}

Based on the die size of pellet machine, the pellet was cylindrical in shape with approximately $4.0 \mathrm{~mm}$ diameter and $1 \mathrm{~cm}$ long (Figure 1). The measured physical properties of each pellet type including composition, density and porosity are provided in Table 1. It was observed that the theoretical porosity increased with the increase in lime proportion. Type 3 pellet had the highest porosity (14\%) which might be resulted due to the bigger particle size of lime compared to clay and fly ash. At the same time, the pellet 
density variation was not significant. This result indicated that the pellet porosity could be adjusted by varying lime content without impacting the pellet density.

\section{(Figure 1)}

\section{(Table 1)}

Based on EDS analysis result, the main component of the pellet was found to be metallic (calcium, iron, potassium, silicon, and aluminum) oxides (Table 2). The type 3 pellet had the highest calcium proportion $16.46 \%$, but the least aluminum content. The difference in iron composition among three pellets was not significant.

\section{(Table 2)}

\subsection{Absorption ability test}

The absorption test was conducted to compare the efficiency of pellets to remove dissolved phosphate. The result from the pellet absorption test is provided in Figure 2. The variation in $\mathrm{P}$ concentration in the solution for four different pellets is shown in Figure $2 A$. The result indicated that pellet type 0 had the highest absorption efficiency. For this pellet, $\mathrm{P}$ concentration in solution $(1 \mathrm{mg} / \mathrm{L}$ in the beginning) reduced by $80 \%$ in 30 seconds after the pellet was added. With 10 min contact time, almost all $\mathrm{P}$ in the solution was absorbed by the pellet. On the contrary, the $\mathrm{P}$ absorption rate of pellets with lime was much slower than pellet without lime (type 0). The $\mathrm{P}$ absorption efficiencies of four types pellet were significantly different to each other, based on the ANOVA result ( $p<0.05$, between groups). This result indicated that the existence of lime in pellet would 
affect the pellet $\mathrm{P}$ absorption rate. For the pellets with added lime, the removal time for $80 \%$ reduction in $\mathrm{P}$ concentration for type 1, type 2 type 3 pellets were 28,20 , and 15 mins, respectively.

\subsection{Heavy metal leaching test}

The heavy metal leaching test was conducted after absorption efficiency test. The ICP-MS test result revealed that type 0 pellet resulted in the highest $\mathrm{Cr}$ leaching compared to other three pellets with lime. The $\mathrm{Cr}$ concentration in the leachate from type 0 pellet after $24 \mathrm{hr}$ contact time was 2.5 times higher than the recommended $\mathrm{Cr}$ concentration limit $(100 \mu \mathrm{g} / \mathrm{L})$ in drinking water by the US Environmental Protection Agency (EPA) National Primary Drinking Water Regulations (NPDWR, 2009). The Cr leaching from other three pellets was under the limit set by EPA. All other heavy metal (As, $\mathrm{Cd}, \mathrm{Cu}, \mathrm{Hg}, \mathrm{Mn}, \mathrm{Mn}, \mathrm{Pb}$, and $\mathrm{Zn}$ ) concentration was under the ICP-MS detection limit $(0.001 \mu \mathrm{g} / \mathrm{L})$. Because of observed heavy metal leaching problem, type 0 pellet was included in the preliminary analysis only and not analyzed further in detail in this study. The result from $\mathrm{Cr}$ leaching test is presented in Figure $2 B$.

The type 3 pellet was found to leach the smallest amount of $\mathrm{Cr}$ which was measured to be $30 \mu \mathrm{g} / \mathrm{L}$ in $5 \mathrm{~h}$ contact time when the Cr concentrations in the leachate were $58 \mu \mathrm{g} / \mathrm{L}$ and $56 \mu \mathrm{g} / \mathrm{L}$ for type 1 and type 2 pellets, respectively. But after $24 \mathrm{hr}, \mathrm{Cr}$ concertations in the leachate for all three type pellets were not significantly different from each other. The 
desorption test result showed all the leachate $\mathrm{P}$ concentration was under the detected limit $(0.04 \mathrm{mg} / \mathrm{L})$.

\section{(Figure 2)}

\subsection{Isotherm fitting}

After the absorption and desorption test, absorption isotherm curve for each type of pellet was developed. Figure 3 shows the amount of adsorbed P ions per unit weight of pellet and unabsorbed $\mathrm{P}$ ions concentration in solution at equilibrium for each type pellet. The absorbed $\mathrm{P}$ concentration increased with the concentration equilibrium $\left(\mathrm{C}_{\mathrm{eq}}\right)$ for all three pellets. The fitted values of $\mathrm{k}$ and $\mathrm{n}$ are summarized in Table 3 . The value of saturation absorption capacity $\left(\mathrm{Q}_{\text {sat }}\right)$ was computed to be $0.69 \mathrm{mg} / \mathrm{g}, 1.24 \mathrm{mg} / \mathrm{g}$ and $1.98 \mathrm{mg} / \mathrm{g}$ for type 1, 2 and 3 pellets, respectively. This result implied that $\mathrm{Q}_{\text {sat }}$ increased as the lime proportion in the pellet increased. The $\mathrm{k}$ values also increased with the proportion of lime in pellets $(1.21 \mathrm{~L} / \mathrm{mg}, 1.82 \mathrm{~L} / \mathrm{mg}$ to $2.31 \mathrm{~L} / \mathrm{mg}$ for type 1,2 and 3 pellets respectively (Table 3). This result indicated that high lime proportion improved the absorption interface condition and enhanced the affinity of $\mathrm{P}$ ions on the pellet. Simultaneously, the pellet surface became more homogeneous following the rise of heterogeneity index $n$. This phenomenon was validated by the observation from ESEM (the result is provided in section 3.6). 


\section{(Figure 3)}

\section{(Table 3)}

\subsection{Effect of $p H$}

The $\mathrm{pH}$ plays a significant role in the $\mathrm{P}$ absorption on the pellet. The $\mathrm{pH}$ effect on $\mathrm{P}$ uptake from each type of pellet is presented in Figure 4. After $24 \mathrm{hr}$ immersion in solutions with $40 \mathrm{mg} / \mathrm{L}$ concentration of $\mathrm{P}$, the equilibrium sorbate quantity on each type pellet showed noticeable difference under the different $\mathrm{pH}$ condition (Figure 4A). Especially, the lower initial $\mathrm{pH}$ of the solution resulted in the smaller equilibrium sorbate quantity. From the Langmuir-Freundlich isotherm result, the theoretical equilibrium sorbates were $0.69 \mathrm{mg} / \mathrm{g}, 1.24 \mathrm{mg} / \mathrm{g}$ and $1.98 \mathrm{mg} / \mathrm{g}$ for type 1,2 , and 3 pellets respectively. But equilibrium sorbate under $\mathrm{pH} 4$ for each type pellet dropped to $0.3 \mathrm{mg} / \mathrm{g}$, $0.71 \mathrm{mg} / \mathrm{g}$ and $1.37 \mathrm{mg} / \mathrm{g}$, respectively. When $\mathrm{pH}$ reached to 10 , the equilibrium sorbate quantities on each pellets were close to the theoretical equilibrium sorbate $(0.69 \mathrm{mg} / \mathrm{g}$, $1.24 \mathrm{mg} / \mathrm{g}$ and $1.98 \mathrm{mg} / \mathrm{g}$ for type 1,2 , and 3 pellets respectively). The change in $\mathrm{pH}$ for the pellet solution was monitored, and the result supported the above deduction (Figure $4 B)$. The initial $\mathrm{pH}$ of $100 \mathrm{mg} / \mathrm{L}$ of $\mathrm{P}$ solution was 5.01, and the $\mathrm{pH}$ increased after pellets were placed in. the solution. The solution with Type 3 pellet had the highest $\mathrm{pH}$ increase, under which the absorption ability significantly improved. This observation supports the result presented in Figure 4A. 


\section{(Figure 4)}

\subsection{Pellet surface structure characteristic}

In this study, the ESEM-EDS technique was used to investigate the presence and distribution of various compounds (elements) on the pellet surface and identify the functional mechanism of $\mathrm{P}$ absorption. The ESEM-EDS technique could provide helpful information on the pellet composition and a possible reason for variation in $\mathrm{P}$ uptake efficiencies of pellets. The Figure 5 shows the EDS spectrum of the selected area on each pellet. The elements identified from EDS spectra of each type sample include oxygen, calcium, silicon, aluminum, potassium, and iron. Based on the excitation energy level of each peak, the element contained in each type pellets were identical. But the concentrations of the element were different, according to the counts of detected excited X-ray.

\section{(Figure 5)}

ESEM-EDS maps of elemental distribution on pellet surface revealed more details of the absorption mechanism besides chemical examination. The elements such as $\mathrm{Al}, \mathrm{Ca}$ and Fe were the primary function elements distributed over the surface. The ESEM chart and 
EDS maps (Al, $\mathrm{Ca}$ and $\mathrm{Fe})$ of the featured area on each type of pellet are illustrated in

Figure 6. For type 1 pellet, there was an apparent cluster of crystalloid in the middle of ESEM chart (Figure 6a), and this band of crystalloid was most likely iron oxide based on the result from Figure 6d. Although Ca (Figure 6c) and Fe (Figure 6d) were scattered in the same area, there was a clear boundary between these two elements. It was also observed that the most $\mathrm{Ca}$ particles surrounded iron oxide. This observation implied that the iron oxide would form cluster when the lime proportion is less. Because of the cluster formation, the specific surface area of iron oxide declined drastically compared to fully disperse condition. This might be the reason for the lower absorption efficiency of pellet type 1 . Moreover, the results obtained from the chemical test also indicated the index of heterogeneity number is lower for type 1 pellet.

Similarly, ESEM chart and EDS map for type 2 pellet are presented in Figures 6e, 6f, $6 \mathrm{~g}$, and $6 \mathrm{f}$. Type 2 pellet seemed to be more porous compared to type 1 pellet (Figure $6 e$ ). Although the chemical composition for type 2 pellet seemed similar to type 1 pellet as observed in Figure $5 a$, the crystalloid structure appeared protruding and had bigger crystalloid size than type 1 pellet (Figure 6e).

On the contrary, the distribution of $\mathrm{Ca}$ and Fe in type 3 pellet was much uniform than type 1 and type 2 pellet as observed in Figures $6 \mathrm{i}, 6 \mathrm{j}, 6 \mathrm{k}$, and 6l. It was also detected that Al-rich spherical shaped particles were distributed evenly in type 3 pellet (Figure 6i). The iron oxide crystalloids were alternately positioned in between the gap of spherical 
particles. Based on these observations, it can be postulated that the uniform structure like figure 6i will have higher $\mathrm{P}$ absorption efficiency compared to the random surface structure as observed for type 1 and 2 pellets.

\section{(Figure 6)}

\section{Discussion}

The $\mathrm{P}$ adsorption is an exchange reaction which takes place on the surface of calcium, iron, and aluminum hydroxides. Binuclear or bridging complexes are formed between $\mathrm{HPO}_{4}{ }^{2-}$ ions and metal oxide surfaces and $\mathrm{OH}_{2}$ and $\mathrm{OH}^{-}$are displaced (Vohla et al., 2011). So, materials rich in calcium, iron or aluminum oxide can be a proper filter material for $\mathrm{P}$ absorption. Based on the element composition result presented in Table 2, fly ash can be a good alternative (Vohla et al., 2011).

An earlier study has indicated that $\mathrm{P}$ absorption pattern on the pellet with an active component like metal oxide followed both Langmuir and Freundlich adsorption isotherm (Jeppu and Clement, 2012). The Langmuir adsorption isotherm builds on the assumption that monolayer coverage on a homogeneous surface with identical adsorption sites. The Freundlich adsorption isotherm, on a heterogeneous surface, can be derived from the assumption that the adsorption sites are distributed exponentially. Both of these phases are present during the $\mathrm{P}$ absorption process on the pellet, as reported by Littler et al. 
(2013). Langmuir process occurs when P ions are removed from the solution and become attached to the surface of the pellet. Then if the adsorbed P ions diffuse into the solid, Freundlich process occurs. Adsorbed P may become trapped on the surface of pellet if any Fe or $\mathrm{Al}$ oxide coating is precipitated on the pellet (Turiel et al., 2003).

In this study, it was observed that the higher lime proportion would increase the rate of $\mathrm{P}$ removal from the solution. During the pellet stirring process, the Dicalcium Ferrite $\left(2 \mathrm{CaO} \cdot \mathrm{Fe}_{2} \mathrm{O}_{3}\right)$ and Calcium Oxide-Monocalcium Aluminate $\left(\mathrm{CaO} \cdot \mathrm{Al}_{2} \mathrm{O}_{3}\right)$ were formed by the reaction of $\mathrm{CaO}$ with $\mathrm{Fe}_{2} \mathrm{O}_{3}$ and $\mathrm{Al}_{2} \mathrm{O}_{3}$ (equation 3 and equation 4) in pellet along with the rise in temperature (Touzo et al., 2013). This process dramatically reduced the $\mathrm{P}$ absorption efficiency of fly ash pellet.

$$
\begin{aligned}
& 2 \mathrm{CaO}+\mathrm{Fe}_{2} \mathrm{O}_{3}=2 \mathrm{CaO} \cdot \mathrm{Fe}_{2} \mathrm{O} \\
& \mathrm{CaO}+\mathrm{Al}_{2} \mathrm{O}_{3}=\mathrm{CaO} \cdot \mathrm{Al}_{2} \mathrm{O}_{3} .
\end{aligned}
$$

The results presented in figure 3 suggested that pellet $\mathrm{P}$ absorption ability would be enhanced under the high $\mathrm{pH}$ condition, and the alkalinity provided by lime assisted in the process. The $\mathrm{pH}$ of pellet surface changed after lime was added, which could also impact the $\mathrm{P}$ absorption process. $\mathrm{CaO}$ (contained in lime) is also a functional compound for $\mathrm{P}$ uptake. Along with the increase of in the lime proportion in the pellet, $\mathrm{P}$ absorption rate also increased. Earlier studies have shown the similar results on calcium-based $\mathrm{P}$ filter materials (Kunaschk et al., 2015; Spears et al., 2013; Yin and Kong, 2014; Yin et al., 2013). At the same time, the higher lime proportion in the pellet resulted in lesser $\mathrm{Cr}$ 
leaching. Earlier studies have reported that the alkalinity added by lime might be the reason for the heavy metal Cr immobilization (He and Traina, 2005; Reddy et al., 2014).

Looking into the microstructure of pellet, the negative charge provided by bentonite clay was probably the reason for the formation of iron oxide crystalloid by activating the ferroelectricity phenomenon during the pellet stirring process (Catalan et al., 2015; Jayarathna et al., 2015). This change in crystal structure might have enhanced P adsorption for type 2 compared to type 1 pellet due to increasing in lime and the reduction in bentonite clay proportion (Brännvall et al., 2015). An earlier study has demonstrated that bentonite clay could enhance the iron oxide dispersion in a pellet (Kobayashi et al., 2012).

Before applying the fly ash pellet in the field, further investigation is needed to quantify the saturation time so that the pellet can be replaced on time before it starts serving as a P sourc, rathern than sink. In an earlier study, Xie et al., (2015) investigated P uptake by zeolite modified fly ash pellet and suggested that a saturation time of 17 days (17 cycles) under $20 \mathrm{mg} / \mathrm{L}$ phosphate solution. The fly ash pellet, with lime and clay developed in this study, should be last much longer than 17 days to reach saturation time under the lower $\mathrm{P}$ concentration condition in subsurface drainage water. Based on the efficiency and the pellet durability, it can be used as a filter at the tile outlet for subsurface drainage water treatment (which is under the frozen soil layer in most cases). 
Kirkkala et al., (2012a, b) have provided good examples of applying such filters at the field scale.

\section{Conclusion}

In this study, the phosphate adsorption on the pellets made up of various proportions of fly ash, lime, and bentonite clay was examined. The chemical and ESEM-EDS tests were performed to investigate the general characteristic and $\mathrm{P}$ absorption efficiency of three types of pellets. It was observed that the adsorption equilibrium time was about $24 \mathrm{hr}$. Phosphate adsorption increased with $\mathrm{pH}$. The higher lime proportion in pellet resulted in less heavy metal (Cr) leaching. During the desorption test, there was no phosphate desorption detected even after $24 \mathrm{hr}$. The phosphate adsorption on the pellets followed the Langmuir-Freundlich model. The maximum phosphate adsorption capacity (Qmax) of the pellets were $0.69,1.24$ and $1.98 \mathrm{mg} / \mathrm{g}$ for type 1,2 , and 3 , respectively, based on the fitted Langmuir-Freundlich model. It was observed that the chemical and physical interaction of lime and clay with fly ash created a particular structure. The variation in lime and clay proportions also altered the pellet surface structure. The difference in pellet surface texture and structure are believed to be responsible for the change in phosphate absorption efficiency. With further investigation, the pellets have a potential to treat contaminated water with high $\mathrm{P}$ concentration from the point and non-point sources. 


\section{Acknowledgement}

This work was supported by the open project (No. HCK201507) of State Key Laboratory of Urban Water Resource and Environment, Harbin Institute of Technology. It was also partially supported by the USDA National Institute of Food and Agriculture, Hatch project ILLU-741-379. 


\section{References}

Allen, B.L., Mallarino, A.P., Lore, J.F., Baker, J.L., Haq, M.U., 2012. Phosphorus Lateral Movement through Subsoil to Subsurface Tile Drains. Soil Sci. Soc. Am. J. 76, 710-717.

Allred, B.J., 2010. Laboratory batch test evaluation of five filter materials for removal of nutrients and pesticides from drainage water. Trans. ASABE 53, 39-54.

Baker, J.L., Campbell, K.L., Johnson, H.P., Hanway, J.J., 1975. Nitrate, phosphorus, and sulfate in subsurface drainage water. J. Environ. Qual. 4, 406-412.

Bhattarai, R., Kalita, P.K., Patel, M.K., 2009. Nutrient transport through a Vegetative Filter Strip with subsurface drainage. J. Environ. Manage. 90, 1868-1876.

Bird, S.C., Drizo, A., 2010. EAF Steel Slag Filters for Phosphorus Removal from Milk Parlor Effluent: The Effects of Solids Loading, Alternate Feeding Regimes and In-Series Design. Water 2, 484-499.

Bock, E., Smith, N., Rogers, M., Coleman, B., Reiter, M., Benham, B., Easton, Z.M., 2015. Enhanced nitrate and phosphate removal in a denitrifying bioreactor with biochar. J. Environ. Qual. 44, 605-613.

Brännvall, E., Wolters, M., Sjöblom, R., Kumpiene, J., 2015. Elements availability in soil fertilized with pelletized fly ash and biosolids. J. Environ. Manage. 159, 27-36. 
Braskerud, B.C., Hartnik, T., Lovstad, O., 2005. The effect of the redox-potential on the retention of phosphorus in a small constructed wetland. Water Sci. Technol. 51, 127-134.

Catalan, G., Jimenez, D., Gruverman, A., 2015. Ferroelectrics: Negative capacitance detected. Nat. Mater. 14, 137-139.

Daigh, A.L.M., Zhou, X.B., Helmers, M.J., Pederson, C.H., Horton, R., Jarchow, M., Liebman, M., 2015. Subsurface Drainage Nitrate and Total Reactive Phosphorus Losses in Bioenergy-Based Prairies and Corn Systems. J. Environ. Qual. 44, 1638-1646.

Eastman, M., Gollamudi, A., Stampfli, N., Madramootoo, C.A., Sarangi, A., 2010. Comparative evaluation of phosphorus losses from subsurface and naturally drained agricultural fields in the Pike River watershed of Quebec, Canada. Agric. Water Manage. 97, 596-604.

Gachter, R., Ngatiah, J.M., Stamm, C., 1998. Transport of phosphate from soil to surface waters by preferential flow. Environ. Sci. Technol. 32, 1865-1869.

Gentry, L.E., David, M.B., Royer, T.V., Mitchell, C.A., Starks, K.M., 2007. Phosphorus transport pathways to streams in tile-drained agricultural watersheds. J. Environ. Qual. $36,408-415$.

Ginting, D., Moncrief, J.F., Gupta, S.C., 2000. Runoff, solids, and contaminant losses into surface tile inlets draining lacustrine depressions. J. Environ. Qual. 29, 551-560. 
Goodwin, G.E., Bhattarai, R., Cooke, R., 2015. Synergism in nitrate and orthophosphate removal in subsurface bioreactors. Ecol. Eng. 84, 559-568.

He, Y.T., Traina, S.J., 2005. Cr(VI) Reduction and Immobilization by Magnetite under Alkaline pH Conditions: The Role of Passivation. Environ. Sci. Technol. 39, 4499-4504.

Heathwaite, A.L., Dils, R.M., 2000. Characterising phosphorus loss in surface and subsurface hydrological pathways. Sci. Total Environ. 251, 523-538.

Hornbuckle, J.W., Christen, E.W., Faulkner, R.D., 2007. Evaluating a multi-level subsurface drainage system for improved drainage water quality. Agric. Water Manage. 89, 208-216.

Izquierdo, M., Querol, X., 2012. Leaching behaviour of elements from coal combustion fly ash: An overview. Int. J. Coal Geol. 94, 54-66.

Jankowski, J., Ward, C.R., French, D., Groves, S., 2006. Mobility of trace elements from selected Australian fly ashes and its potential impact on aquatic ecosystems. Fuel 85, $243-256$.

Jayarathna, L., Bandara, A., Ng, W.J., Weerasooriya, R., 2015. Fluoride adsorption on gamma - $\mathrm{Fe}_{2} \mathrm{O}_{3}$ nanoparticles. J. Environ. Health Sci. Eng. 13, 54.

Jeppu, G.P., Clement, T.P., 2012. A modified Langmuir-Freundlich isotherm model for simulating pH-dependent adsorption effects. J. Contam. Hydrol. 129-130, 46-53. 
Karlfeldt Fedje, K., Ekberg, C., Skarnemark, G., Steenari, B.-M., 2010. Removal of hazardous metals from MSW fly ash-An evaluation of ash leaching methods. J. Hazard. Mater. 173, 310-317.

King, K.W., Williams, M.R., Macrae, M.L., Fausey, N.R., Frankenberger, J., Smith, D.R., Kleinman, P.J.A., Brown, L.C., 2015. Phosphorus Transport in Agricultural Subsurface Drainage: A Review. J. Environ. Qual. 44, 467-485.

Kirkkala, T., Ventelä, A.-M., Tarvainen, M., 2012a. Fosfilt filters in an agricultural catchment: a long-term field-scale. Agr. Food Sci. 21, 237-246.

Kirkkala, T., Ventelä, A.-M., Tarvainen, M., 2012b. Long-Term Field-Scale Experiment on Using Lime Filters in an Agricultural Catchment. J. Environ. Manage. 41, 410-419. Kleinman, P.J.A., Sharpley, A.N., Withers, P.J.A., Bergstrom, L., Johnson, L.T., Doody, D.G., 2015. Implementing agricultural phosphorus science and management to combat eutrophication. Ambio 44, S297-S310.

Kobayashi, K., Horiuchi, S., Kumai, R., Kagawa, F., Murakami, Y., Tokura, Y., 2012. Electronic Ferroelectricity in a Molecular Crystal with Large Polarization Directing Antiparallel to Ionic Displacement. Phys. Rev. Lett. 108, 237601.

Kronvang, B., Vagstad, N., Behrendt, H., Bogestrand, J., Larsen, S.E., 2007. Phosphorus losses at the catchment scale within Europe: an overview. Soil Use Manage. 23, 104-116. 
Kunaschk, M., Schmalz, V., Dietrich, N., Dittmar, T., Worch, E., 2015. Novel regeneration method for phosphate loaded granular ferric (hydr)oxide - A contribution to phosphorus recycling. Water Res. 71, 219-226.

Kung, K.J.S., Steenhuis, T.S., Kladivko, E.J., Gish, T.J., Bubenzer, G., Helling, C.S., 2000. Impact of preferential flow on the transport of adsorbing and non-adsorbing tracers. Soil Sci. Soc. Am. J. 64, 1290-1296.

Laubel, A., Jacobsen, O.H., Kronvang, B., Grant, R., Andersen, H.E., 1999. Subsurface drainage loss of particles and phosphorus from field plot experiments and a tile-drained catchment. J. Environ. Qual. 28, 576-584.

Li, M., Zhu, B., Hou, Y.L., 2010. Phosphorus release risk on a calcareous purple soil in southwest China. Int. J. Environ. Pollut. 40, 351-362.

Littler, J., Geroni, J.N., Sapsford, D.J., Coulton, R., Griffiths, A.J., 2013. Mechanisms of phosphorus removal by cement-bound ochre pellets. Chemosphere 90, 1533-1538.

Liu, Y.B., Corluy, J., Bahremand, A., De Smedt, F., Poorova, J., Velcicka, L., 2006. Simulation of runoff and phosphorus transport in a carpathian catchment, Slovakia. River Res. Appl. 22, 1009-1022.

Melland, A.R., Mc Caskill, M.R., White, R.E., Chapman, D.F., 2008. Loss of phosphorus and nitrogen in runoff and subsurface drainage from high and low input pastures grazed by sheep in southern Australia. Aust. J. Soil Res. 46, 161-172. 
Nielsen, M.H., Styczen, M., Ernstsen, V., Petersen, C.T., Hansen, S., 2010. Field Study of Preferential Flow Pathways in and between Drain Trenches. Vadose Zone J. 9, 1073-1079.

Penn, C.J., Bryant, R.B., Kleinman, P.J.A., Allen, A.L., 2007. Removing dissolved phosphorus from drainage ditch water with phosphorus sorbing materials. J. Soil Water Conserv. 62, 269-276.

Reddy, K.R., Xie, T., Dastgheibi, S., 2014. Removal of heavy metals from urban stormwater runoff using different filter materials. J. Environ. Chem. Eng. 2, 282-292.

Reid, D.K., Ball, B., Zhang, T.Q., 2012. Accounting for the Risks of Phosphorus Losses through Tile Drains in a Phosphorus Index. J. Environ. Qual. 41, 1720-1729.

Ruark, M., Madison, A., Cooley, E., Stuntebeck, T., Komiskey, M., 2012. Phosphorus loss from tile drains: should we be concerned?. In Proc. 2012 Wisconsin Crop Manage. Conf. pp. 9-14.

Simard, R.R., Beauchemin, S., Haygarth, P.M., 2000. Potential for preferential pathways of phosphorus transport. J. Environ. Qual. 29, 97-105.

Smith, D.R., Francesconi, W., Livingston, S.J., Huang, C.H., 2015. Phosphorus losses from monitored fields with conservation practices in the Lake Erie Basin, USA. Ambio 44, S319-S331. 
Smith, R.V., Lennox, S.D., Jordan, C., Foy, R.H., McHale, E., 1995. Increase in soluble phosphorus transported in drainflow from a grassland catchment in response to soil phosphorus accumulation. Soil Use Manage. 11, 204-209.

Soinne, H., Hovi, J., Tammeorg, P., Turtola, E., 2014. Effect of biochar on phosphorus sorption and clay soil aggregate stability. Geoderma 219-220, 162-167.

Spears, B.M., Meis, S., Anderson, A., Kellou, M., 2013. Comparison of phosphorus (P) removal properties of materials proposed for the control of sediment $\mathrm{p}$ release in UK lakes. Sci. Total Environ. 442, 103-110.

Stone, W.W., Wilson, J.T., 2006. Preferential flow estimates to an agricultural tile drain with implications for glyphosate transport. J. Environ. Qual. 35, 1825-1835.

Su, J., van Bochove, E., Auclair, J.C., Theriault, G., Denault, J.T., Bosse, C., Li, X., Hu, C., 2014. Phosphorus algal availability and release potential in suspended and streambed sediments in relation to sediment and catchment characteristics. Agric. Ecosyst. Environ. 188, 169-179.

Touzo, B., Scrivener, K.L., Glasser, F.P., 2013. Phase compositions and equilibria in the $\mathrm{CaO}-\mathrm{Al}_{2} \mathrm{O}_{3}-\mathrm{Fe}_{2} \mathrm{O}_{3}-\mathrm{SO}_{3}$ system, for assemblages containing ye'elimite and ferrite $\mathrm{Ca}_{2}(\mathrm{Al}, \mathrm{Fe}) \mathrm{O}_{5}$. Cem. Concr. Res. 54, 77-86.

Turiel, E., Perez-Conde, C., Martin-Esteban, A., 2003. Assessment of the cross-reactivity and binding sites characterisation of a propazine-imprinted polymer using the Langmuir-Freundlich isotherm. Analyst 128, 137-141. 
Uusitalo, R., Turtola, E., Kauppila, T., Lilja, T., 2001. Particulate phosphorus and sediment in surface runoff and drainflow from clayey soils. J. Environ. Qual. 30, 589-595.

Van Es, H.M., Schindelbeck, R.R., Jokela, W.E., 2004. Effect of manure application timing, crop, and soil type on phosphorus leaching. J. Environ. Qual. 33, 1070-1080.

Vohla, C., Koiv, M., Bavor, H.J., Chazarenc, F., Mander, U., 2011. Filter materials for phosphorus removal from wastewater in treatment wetlands-A review. Ecol. Eng. 37, 70-89.

Westholm, L.J., 2006. Substrates for phosphorus removal - Potential benefits for on-site wastewater treatment? Water Res. 40, 23-36.

Wright, R.B., Lockaby, B.G., Walbridge, M.R., 2001. Phosphorus availability in an artificially flooded southeastern floodplain forest soil. Soil Sci. Soc. Am. J. 65, 1293-1302.

Xie, J., Lai, L., Lin, L., Wu, D., Zhang, Z., Kong, H., 2015. Phosphate removal from water by a novel zeolite/lanthanum hydroxide hybrid material prepared from coal fly ash. J. Environ. Chem. Eng. 50, 1298-1305.

Xu, J.Z., Zhou, Y.L., Chang, Q., Qu, H.Q., 2006. Study on the factors of affecting the immobilization of heavy metals in fly ash-based geopolymers. Mater. Lett. 60, 820-822. 
Yin, H., Kong, M., 2014. Simultaneous removal of ammonium and phosphate from eutrophic waters using natural calcium-rich attapulgite-based versatile adsorbent. Desalination 351, 128-137.

Yin, H., Kong, M., Fan, C., 2013. Batch investigations on P immobilization from wastewaters and sediment using natural calcium rich sepiolite as a reactive material. Water Res. 47, 4247-4258. 


\section{Figure Captions}

Figure 1. Appearance (top) and surface structure as observed from ESEM (bottom) of pellet type 3 .

Figure 2. Pellet characteristic test result. A. P absorption efficiency of 4 type of pellet. B. Heavy metal leaching test result.

Figure 3. Fitted Langmuir-Freundlich isotherms curves for type 1, 2 and 3 pellets.

Figure 4. A. Effect of $\mathrm{pH}$ on absorption ability of pellet. B. Change in solution $\mathrm{pH}$ with time for three different pellets.

Figure 5. EDS spectra of selected area on each type pellet (x-axis is level of excitation energy, $\mathrm{y}$-axis is the counts of detected excited X-ray).

Figure 6. ESEM-EDS micrograph and maps of distribution of elements on the surface of pellets (x8000). 


\section{Table Captions}

Table 1. Physical properties of pellets.

Table 2. Elemental composition of each type of pellet $(\%)$.

Table 3. Fitted values of Langmuir-Freundlich parameters for each type of pellet (the equation is $\mathrm{q}=\mathrm{Q}_{\text {sat }} \times \mathrm{K} \times \mathrm{C}_{\mathrm{eq}}{ }^{\mathrm{n}} /\left(1+\mathrm{k} \times \mathrm{C}_{\mathrm{eq}}{ }^{\mathrm{n}}\right)$ 


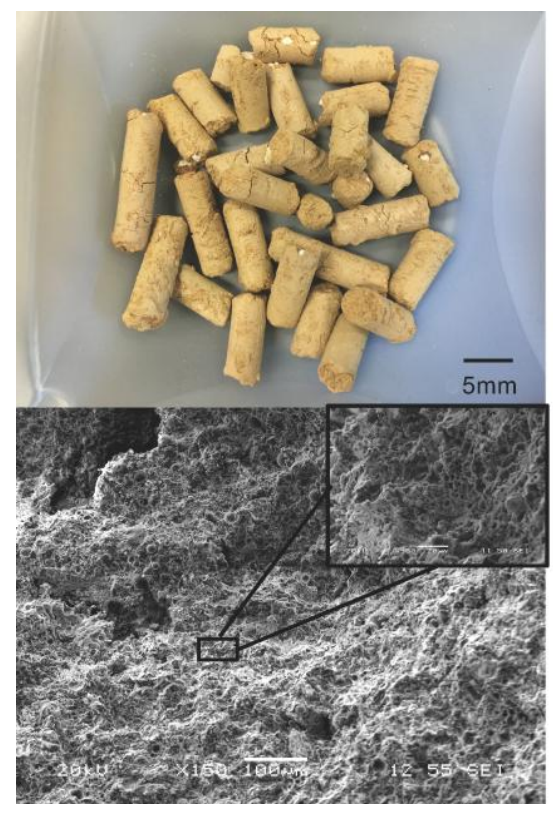



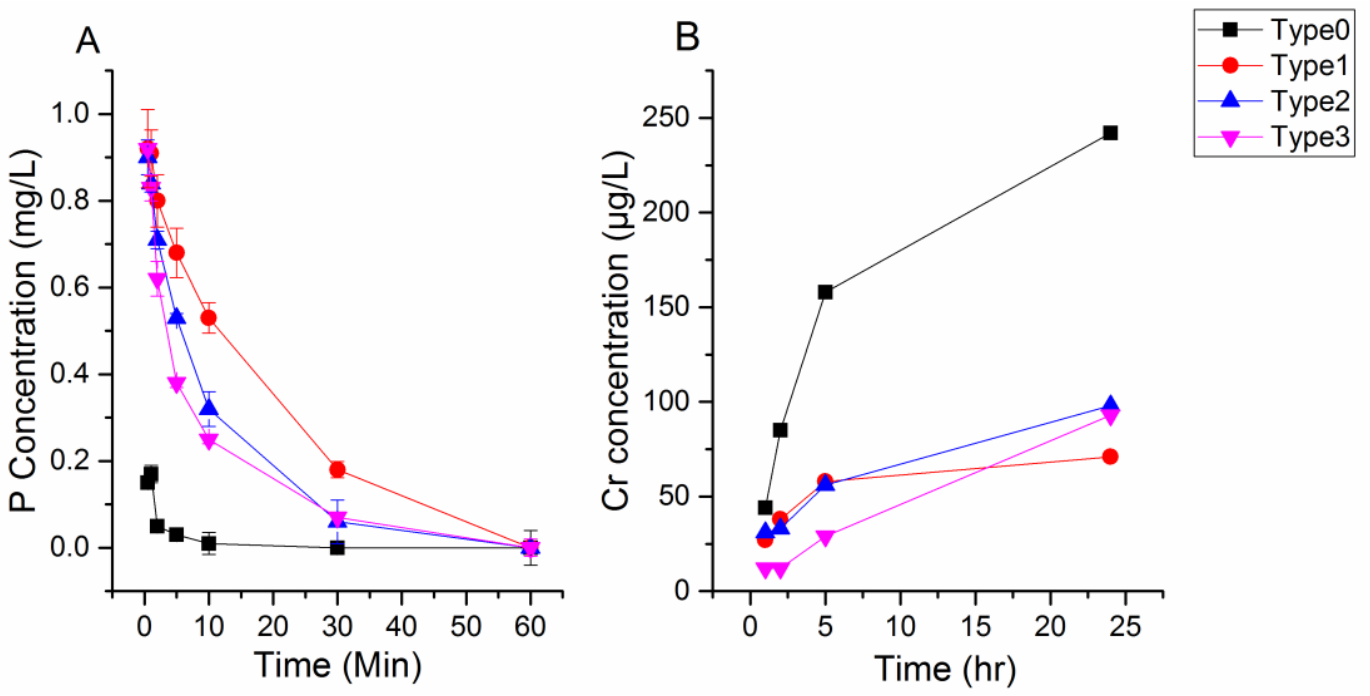


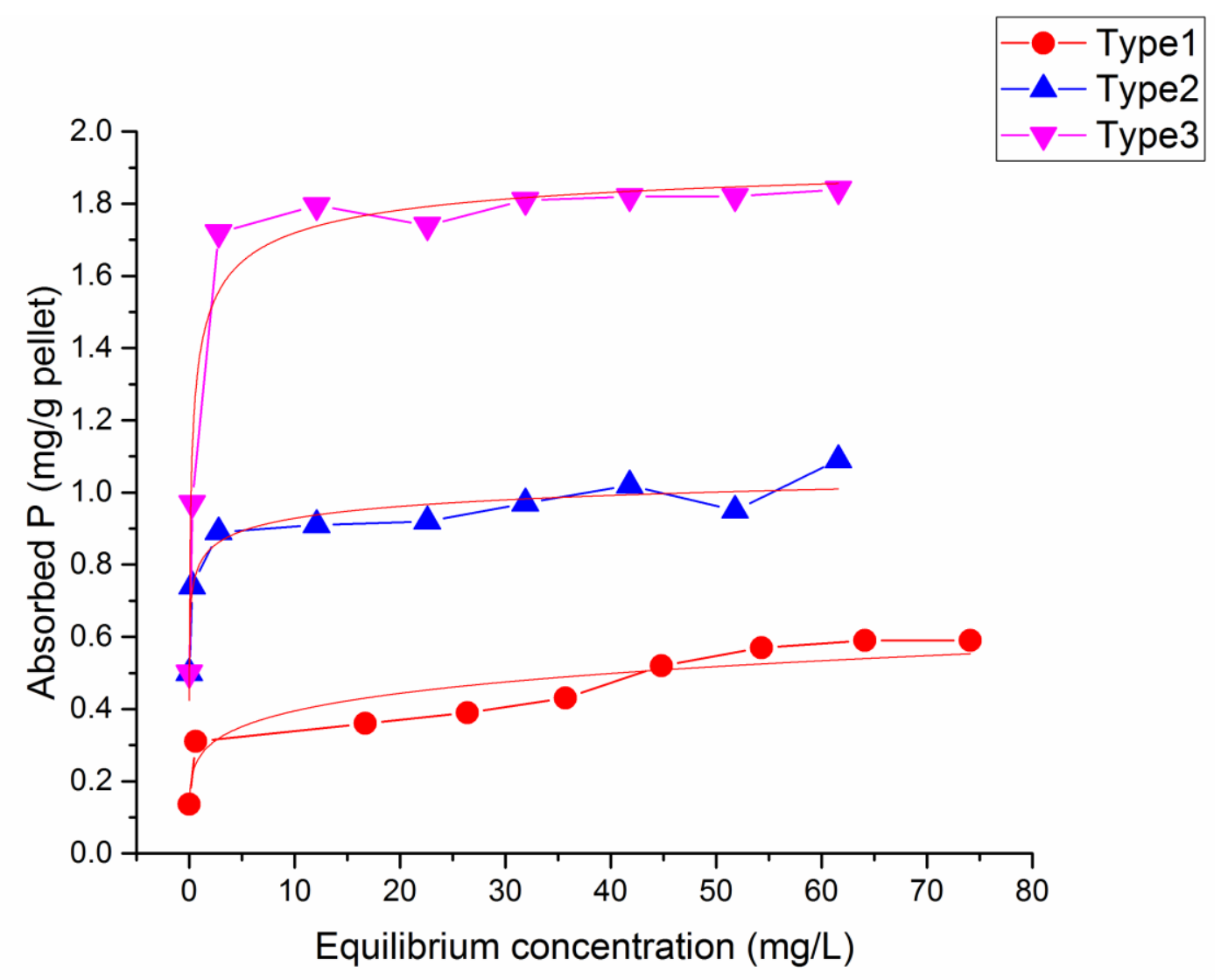



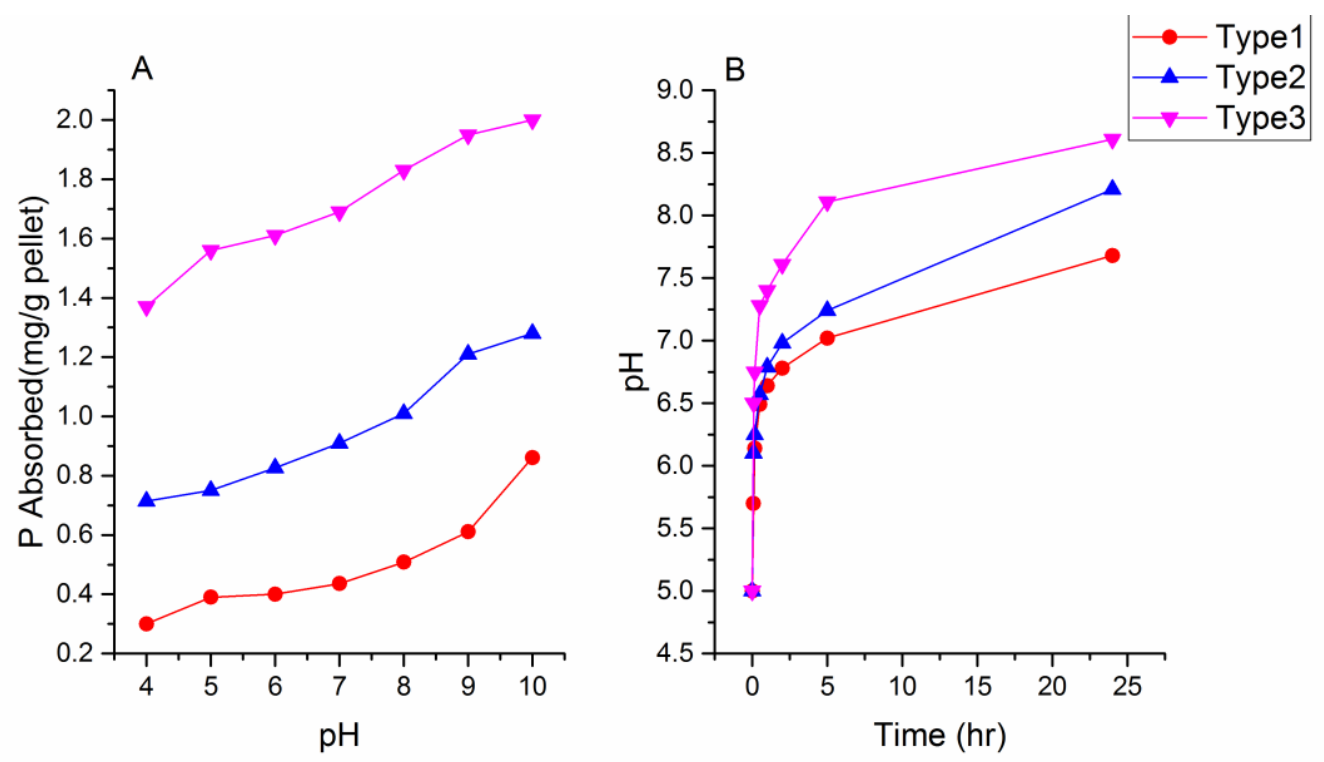

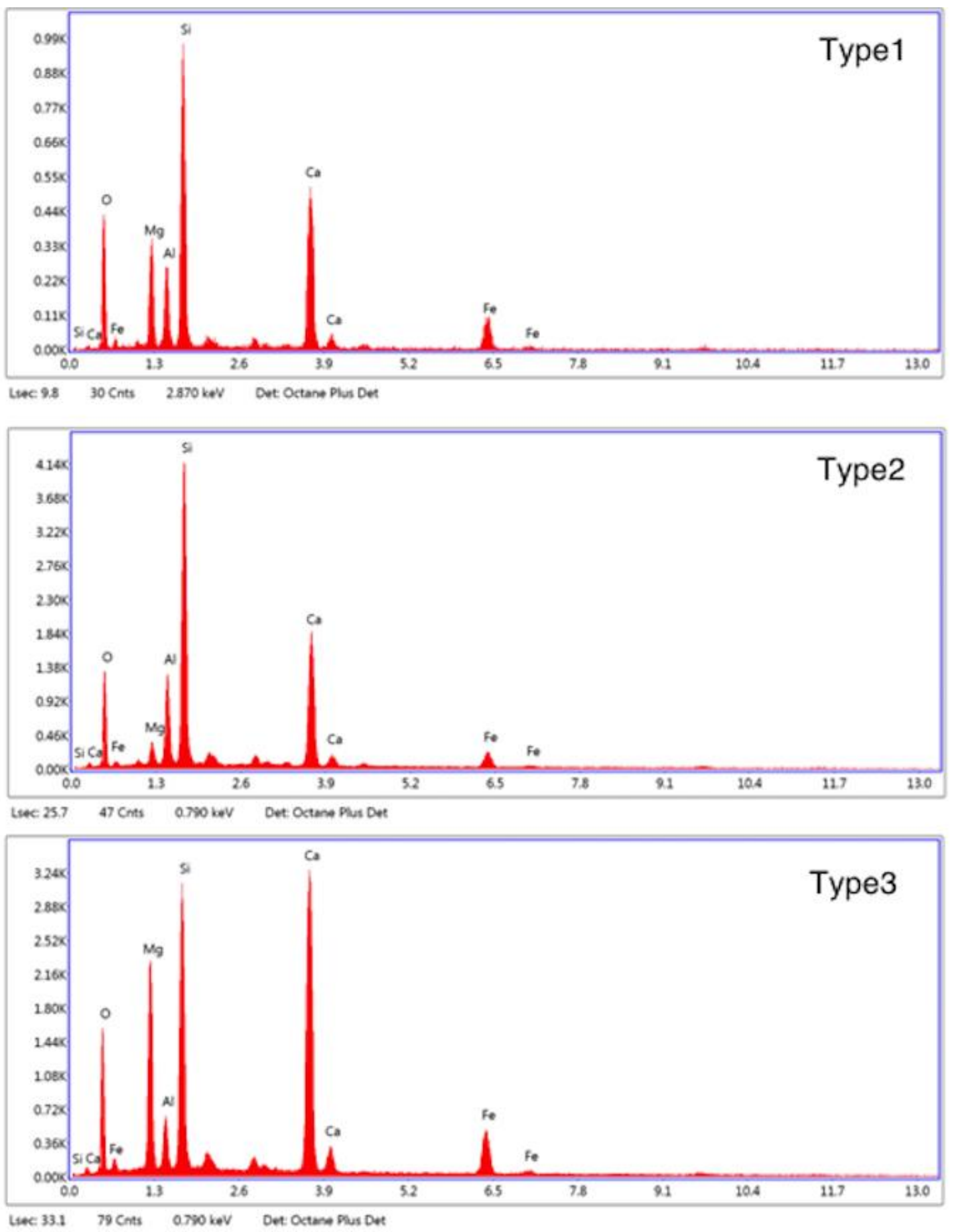


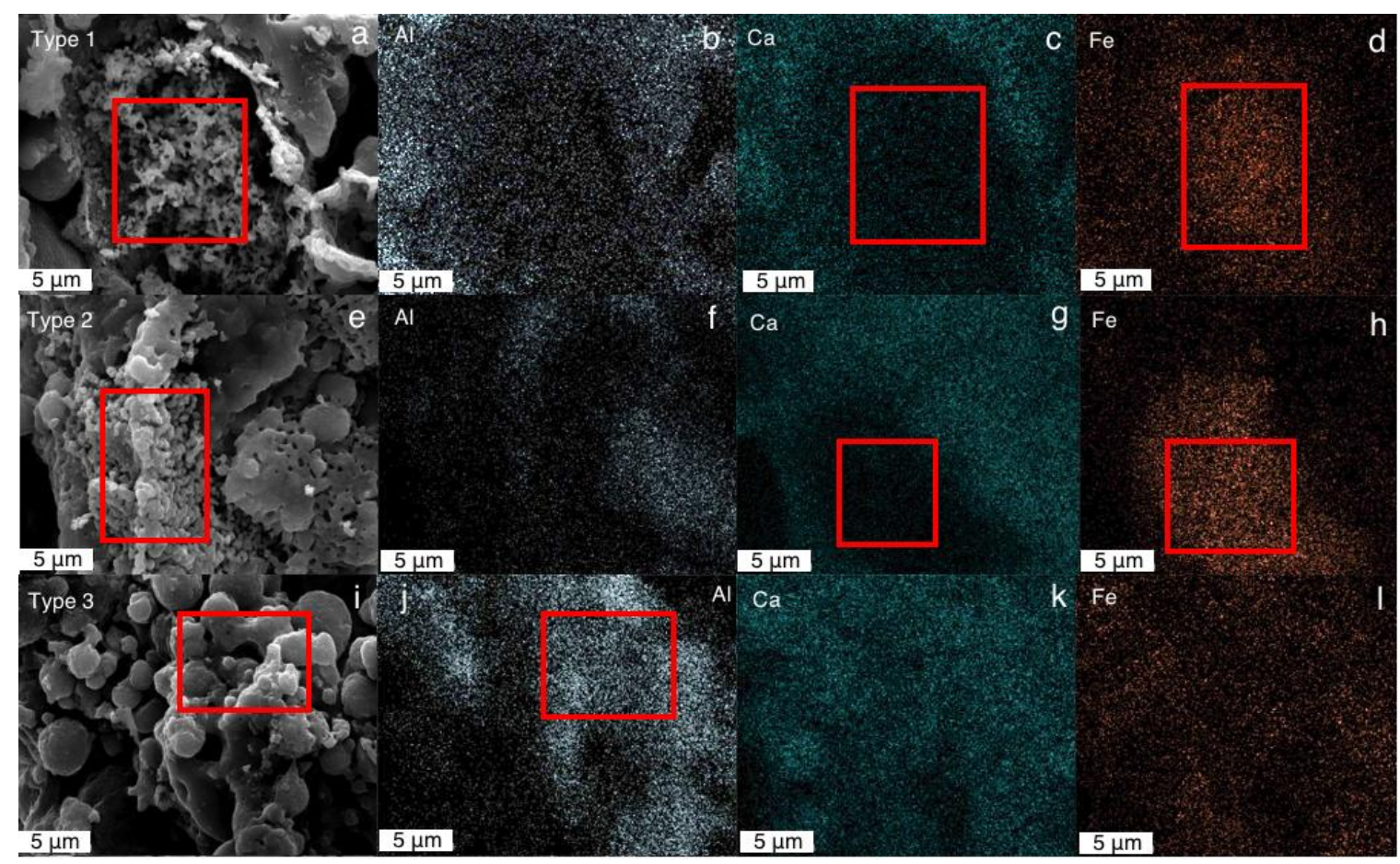


Characterization of fly ash ceramic pellet for phosphorus removal

Table 1 Physical properties of pellets

\begin{tabular}{ccccc}
\hline \multirow{2}{*}{$\begin{array}{c}\text { Variable } \\
\text { Formulation FA: Clay: Lime }(\%)\end{array}$} & \multicolumn{2}{c}{ Density $\left(\mathrm{kg} / \mathrm{m}^{3}\right)$} & \multirow{2}{*}{ Porosity $\varnothing(\%)$} \\
\cline { 3 - 4 } Pellet type 0 & $60: 40: 0$ & 1050.08 & 1025.70 & 0.02 \\
Pellet type 1 & $60: 30: 10$ & 1097.12 & 1011.60 & 0.08 \\
Pellet type 2 & $60: 20: 20$ & 1148.56 & 1003.06 & 0.13 \\
Pellet type 3 & $60: 10: 30$ & 1205.07 & 1037.39 & 0.14 \\
\hline
\end{tabular}


Characterization of fly ash ceramic pellet for phosphorus removal

Table 2 The elemental composition of each type of pellet (\%)

\begin{tabular}{ccccccc}
\hline Variable & $\mathrm{O}$ & $\mathrm{Mg}$ & $\mathrm{Al}$ & $\mathrm{Si}$ & $\mathrm{Ca}$ & $\mathrm{Fe}$ \\
\hline Pellet type 0 & 51.85 & 3.41 & 6.8 & 23.1 & 7.9 & 6.94 \\
Pellet type 1 & 53.91 & 2 & 5.67 & 21.66 & 11.71 & 4.22 \\
Pellet type 2 & 53.49 & 8.11 & 5.27 & 17.23 & 12.55 & 4.19 \\
Pellet type 3 & 50.62 & 12.76 & 2.78 & 12.87 & 16.46 & 4.5 \\
\hline
\end{tabular}


Table 3: Fitted values of Langmuir-Freundlich parameters for each type of pellet (the equation is $q=\mathrm{Q}_{\text {sat }}$

\begin{tabular}{ccccc}
\multicolumn{5}{c}{$\times \mathrm{K}^{\circ} \times \mathrm{C}_{\mathrm{eq}}{ }^{\mathrm{n}} /\left(1+\mathrm{k} \times \mathrm{C}_{\mathrm{eq}}{ }^{\mathrm{n}}\right)$} \\
\hline Type & $Q_{\text {sat }}(\mathrm{mg} / \mathrm{g})$ & $\mathrm{K}(\mathrm{L} / \mathrm{mg})$ & $\mathrm{n}$ & $\mathrm{R}^{2}$ \\
\hline 1 & 0.69 & 1.21 & 0.17 & 0.83 \\
\hline 3 & 1.24 & 1.82 & 0.21 & 0.92 \\
\hline
\end{tabular}

